\title{
Pembubaran Organisasi Kemasyarakatan dalam Perspektif Siyasah Syar'iyyah dan Negara Hukum
}

\author{
Nabih Amer, Rahmat Teguh Santoso Gobel \\ PPs Universitas Negeri Gorontalo, IAIN Sultan Amai Gorontalo \\ e-mail: amer575817@gmail.com; rtsg@iaingorontalo.ac.id
}

\begin{abstract}
This article discusses the problem of the dissolution of social organizations in Indonesia that is not in accordance with the principles of the rule of law. These problems will be answered methodologically using normative legal research. The author uses this legal research because the focus is on studying literature, legislation and court decisions relating to the object of research. Based on the results of the study this article concludes that the 1945 Constitution of the Republic of Indonesia emphasizes the importance of a system of checks and balances in which there needs to be a clear division of power between the executive and judicial functions. This means that in the case of the dissolution of social organizations it is very important to involve the court in deciding the dissolution of the social organization in Indonesia by structuring dispute resolution in the courts using the principle of quick, simple and low cost justice so that the process of dispute resolution of the social organization can be carried out effectively and efficiently.
\end{abstract}

Keywords: Dissolution, Social Organization. Rule of Law

\section{The Dissolution of Community Organizations in the Siyasah Syar'iyyah and the Law State Perspectives}

\begin{abstract}
Abstrak: Artikel ini membahas permasalahan pembubaran organisasi kemasyarakatan di Indonesia yang belum sesuai dengan prinsip negara hukum. Permasalahan tersebut akan dijawab secara metodeologis dengan menggunakan penelitian hukum normatif (normative legal research). Penulis menggunakan penelitian hukum ini dikarenakan fokusnya adalah mengkaji studi literatur, peraturan perundang-undangan dan putusanputusan pengadilan yang berhubungan dengan objek penelitian. Berdasarkan hasil kajian artikel ini menyimpulkan bahwa UUD NRI Tahun 1945 menekankan pentingnya sistem check and balances (pengawasan dan keseimbangan) yang mana perlu ada pembagian kekuasaan yang jelas antara fungsi eksekutif dan yudikatif. Artinya dalam permasalahan pembubaran organisasi kemasyarakatan sangat penting untuk melibatkan pengadilan untuk memutus vonis pembubaran organisasi kemasyarakatan di Indonesia dengan cara melakukan penataan penyelesaian sengketa di pengadilan dengan menggunakan asas peradilan cepat, sederhana dan biaya ringan sehingga proses penyelesaian sengketa pembubaran organisasi kemasyarakatan bisa dilaksanakan secara efektif dan efisien.
\end{abstract}

Kata Kunci: Pembubaran, Organisasi Kemasyarakatan, Negara Hukum 


\section{Pembubaran Organisasi Kemasyarakatan dalam Perspektif Siyasah Syar'iyyah} dan Negara Hukum

\section{A. Pendahuluan}

Organisasi kemasyarakatan (ormas) merupakan peran serta masyarakat dalam melaksanakan pembangunan untuk memajukan kehidupan yang berkeadilan dan kemakmuran. Sebenarnya keberadaan organisasi kemasyarakatan di Indonesia semenjak awal abad ini sudah terbentuk dan mempunyai kedudukan paling strategis bagi proses kebangsaan Indonesia. Bahkan lahirnya partai politik di Indonesia dipelopori oleh sebagian dari organisasi kemasyarakatan sebagai suatu gerakan kebangsaan. ${ }^{1}$

Dinamika perkembangan organisasi kemasyarakatan dan transformasi rezim pemerintahan mampu mengubah paradigma terhadap rancang bangun organisasi kemasyarakatan dalam kehidupan bernegara. Pertumbuhan jumlah organisasi kemasyarakatan, makin menuntut peran, fungsi dan tanggung jawab organisasi kemasyarakatan dalam kehidupan demokrasi saat ini untuk dapat berpartisipasi dalam rangka mewujudkan cita-cita bangsa indonesia. Peningkatan peran dan fungsi organisasi kemasyarakatan dalam pembangunan bangsa dan negara telah berkelindan dengan kesadaran sosial terhadap pentingnya membangun sistem pengelolaan organisasi kemasyarakatan yang memenuhi kaidah organisasi kemasyarakatan yang sehat sebagai organisasi yang demokratis, akuntabel, transparan, mandiri dan profesional. Oleh karena itu, dinamika organisasi kemasyarakatan dengan segala kompleksitasnya menuntut pengelolaan dan pengaturan hukum yang lebih komprehensif melalui undang-undang. ${ }^{2}$

Kebebasan berserikat dan berkumpul adalah jaminan hukum Undang-Undang Dasar Negara Republik Indonesia (UUD NRI) Tahun 1945 yang diberikan kepada setiap warga negara. Kebebasan tersebut bukan merupakan hak yang absolut, artinya kebebasan tersebut tunduk kepada sejumlah pembatasan yang juga harus ditetapkan dalam undang-undang. Hal ini bukan saja merupakan cerminan, melainkan prasyarat

\footnotetext{
${ }^{1}$ Tirta Nugraha Mursitama, Laporan Pengkajian Hukum Tentang Peran Dan Tanggungjawab Organisasi Kemasyarakatan Dalam Pemberdayaan Masyarakat (Jakarta: Pusat Penelitian Dan Pengembangan Sistem Hukum Nasional Badan Pembinaan Hukum Nasional Kementerian Hukum Dan Hak Asasi Manusia RI, 2011), 2.

${ }^{2}$ Catur Wibowo dan Herman Harefa, "Urgensi Pengawasan Organisasi Kemasyarakatan Oleh Pemerintah,” Jurnal Bina Praja, Vol. 7, No. 1, Edisi Maret 2015; 2.
} 
dalam sebuah negara demokrasi. Pembatasan tersebut diperlukan apabila adanya kepentingan untuk melindungi keamanan nasional atau keselamatan publik (national security or public safety), ketertiban umum (public order), perlindungan kesehatan dan moralitas publik (public health or morals), dan perlindungan terhadap hak dan kebebasan pihak lain. ${ }^{3}$

Kebebasan berpendapat dalam pemerintahan Islam adalah hak individu yang mengantarkanya kepada kepentingan dan nuraninya yang tidak boleh dikurangi negara atau ditinggalkan individu. Hal ini penting bagi kondisi pemikiran dan kemanusiaan setiap individu, agar seorang muslim dapat melakukan kewajiban-kewajiban Islamnya. Diantara kewajiban tersebut adalah melakukan amar ma'ruf nahi munkar, yang untuk merealisasikannya membutuhkan dan dituntut kecakapan mengutarakan pendapat secara bebas.

Kebebasan berpendapat ini harus dimanfaatkan untuk tujuan menyebarkan kebaikan, dan tidak untuk menyebarluaskan kejahatan dan kezaliman. Seseorang boleh secara bebas mengemukakan pendapat, akan tetapi jangan sampai melanggar hukum yang mengarah pada perbuatan yang melawan kebenaran, fitnah, penghujatan, mengikuti kemauan sendiri dan menghina keyakinan orang lain. Bagaimanapun juga, dalam keadaan apapun Islam tidak akan mengizinkan perbuatan keji terhadap orang lain dan menghina atas nama kritik. Oleh karena itu kebebasan berpendapat harus sesuai dengan prinsip kaidah umum hukum Islam, yakni mewajibkan setiap manusia supaya menegakkan dan melaksanakan yang benar, menghapus dan menghindari yang salah. $^{4}$

Menurut Hans Kelsen bahwa ada atau tidaknya kompromi yang menyatukan perbedaan pendapat untuk menentukan sebuah tatanan bagi landasan sebuah negara merupakan salah satu esensi demokrasi. Sebuah syarat utama dalam penentuan apakah sebuah negara menganut prinsip demokrasi ataukah tidak sama sekali yaitu terletak pada kompromi. Ada sebuah pegangan dalam memahami negara dengan bercirikan prinsip demokrasi antara lain:

1.

${ }^{3}$ Atip Latipulhayat, "Due Process of Law," Jurnal Ilmu Hukum Padjajaran, Vol. 4 No. 2, 2017;

${ }^{4}$ Muh. In'amuzzahidin, “Konsep Kebebasan Dalam Islam,” Jurnal at-Taqaddum, Vol. 7, No. 2, November 2015; 265-266. 
Pembubaran Organisasi Kemasyarakatan dalam Perspektif Siyasah Syar'iyyah dan Negara Hukum

1) Terdapat kehendak minoritas dan kehendak mayoritas.

2) Kehendak mayoritas tidak bisa menjadi dominasi absolut.

3) Terdapat kompromi dalam menyikapi sebuah permasalahan dan dalam pembentukan sebuah tatanan di antara kehendak mayoritas dengan kehendak minoritas.

4) Tidak ada pemaksaan dalam berkeyakinan dan beragama.

5) Terdapat jamianan kebebasan mengemukakan pendapat, kebebasan berbicara dan kebebasan pers baik melalui konstitusi ataupun melalui kesepakatan adat yang terjadi di sebuah negara.

6) Kompromi yang sehat menjadikan tidak diketemukannya perbenturan kepentingan antara kehendak mayoritas dan kehendak minoritas yang akan biasanya akan berbuah pada anarki. ${ }^{5}$

Eksistensi organisasi kemasyarakatan pada masa kini harus mampu membawa dan memperjuangkan aspirasi dan kehendak masyarakat sebagai medium untuk melaksanakan kegiatan yang edukatif dan bernilai sehingga bermanfaat demi kepentingan bersama yang sejalan dengan amanat Pancasila. Walaupun kodrat sebuah organisasi memiliki pasang-surut dalam menjalankan roda organisasinya, namun semua itu merupakan dinamika yang terus mewarnai kehidupan organisasi kemasyarakatan untuk terus berbuat dan bertindak atas nama kehendak rakyat dan UUD NRI Tahun 1945.

Indonesia yang telah meneguhkan diri menjadi negara hukum yang demokratis merupakan hal yang wajar apabila tiap tahun bermunculan banyak organisasiorganisasi baru, karena konsekuensi logis dari sebuah negara hukum demokratis menghendaki adanya kebebasan dalam mengeluarkan pendapat, berserikat, dan berkumpul sehingga semakin banyak masyarakat yang ingin mendirikan organisasi sebagai wadah untuk mengembangkan potensi kekuatan yang mereka miliki dalam rangka turut serta membangun peradaban bangsa. Meningkatnya jumlah organisasi

${ }^{5}$ HM. Thalhah, "Teori Demokrasi dalam Wacana Ketatanegaraan Perspektif Pemikiran Hans Kelse,” Jurnal Hukum Vol. 16 No. 3, Juli 2009; 416-418. 
kemasyarakatan yang ada paling tidak selaras dengan prinsip-prinsip saling menghormati dan menghargai kebebasan orang lain sepanjang kebebasan tersebut tidak bertentangan dengan peraturan perundang-undangan. Hal ini sangat penting guna menyuburkan kesadaran terhadap pentingnya perjuangan melalui lembaga sehingga masyarakat akan semakin selektif dalam memilih dan berafiliasi dengan organisasi yang memiliki kesamaan ideologi.

Permasalahannya adalah belakangan ini munculnya gerakan-gerakan beberapa organisasi kemasyarakatan yang bertindak dengan kekerasan dan anarkis. Tindakan kekerasan ini seringkali dipicu oleh ego sentris kelompok dengan dalih bahwa hukum sudah tidak berjalan secara mekanis lagi, sehingga dengan mandeknya mekanisme hukum itu banyak dari mereka mengambil jalan sendiri dengan melakukan penindakan non-hukum yang secara jelas melanggar norma hukum. Justru tanpa disadari sesungguhnya tindakan tersebut merupakan perbuatan melawan hukum dan bertentangan dengan Pancasila.

Organisasi kemasyarakatan merupakan entitas dari kebebasan berserikat, berkumpul dan berpendapat yang dijamin dalam UUD NRI Tahun 1945. Jaminan yang diberikan oleh konstitusi tersebut semestinya menjadi instrumen untuk melaksanakan hak dan kewajibannya secara konstitusional dengan memperhatikan kondisi sosial yang aman dalam mengekspresikan kebebasannya dihadapan publik. Patut disadari bahwa ternyata kebebasan tersebut seringkali digunakan tanpa kendali dan tanpa batas yang mana prinsip-prinsip saling menghargai dan menghormati kebebasan orang lain tidak lagi dipatuhi sehingga menimbulkan ketidakstabilan sosial dalam kehidupan berbangsa dan bernegara. Celakanya, tindakan anarkis seolah-seolah dilegitimasi atas nama negara dan agama yang seyogyanya tidak patut dilakukan karena tidak sejalan dengan nafas hidup negara hukum yang demokratis.

Melihat kondisi rill tersebut, justru sangat merugikan dan tidak baik dipertontonkan kepada publik. Apalagi organisasi kemasyarakatan yang tidak pernah berhenti melakukan tindakan-tindakan kekerasan dan anarkis menimbulkan ketidakpercayaan publik terhadap eksistensi organisasi kemasyarakatan dalam memperjuangkan aspirasi masyarakat. Keadaan inilah yang mendorong pemerintah 
Pembubaran Organisasi Kemasyarakatan dalam Perspektif Siyasah Syar'iyyah dan Negara Hukum

untuk bertindak sesuai prosedur hukum yang berlaku guna memastikan keamanan masyarakat berjalan dengan baik. Ketentuan Undang-Undang Nomor 16 Tahun 2017 memberikan kewenangan kepada pemerintah untuk memberikan sanksi tegas kepada organisasi kemasyarakatan. hukuman yang paling berat diterima oleh organisasi kemasyarakatan yang bermasalah adalah pencabutan legalisasi dari negara yang secara otomatis organisasi kemasyarakatan bubar dengan sendirinya.

Problematika pembubaran organisasi kemasyarakatan ini ada dikarenakan maraknya paham anti Pancasila dan radikalisme yang justru berkembang bebas di Indonesia. Tercatat bahwa dalam Pemerintah Republik Indonesia sebelumnya telah terdapat beberapa Organisasi Kemasyarakatan yang dipandang telah melanggar spirit dan nilai-nilai Pancasila dan Konstitusi UUD NRI Tahun 1945 salah satunya yaitu Hizbut Tahrir Indonesia (HTI).

HTI merupakan organisasi Islam yang mendukung berdirinya Khilafah Islamiyah yang bertentangan dengan ideologi negara Indonesia, yaitu Pancasila. Walaupun kegiatan ataupun pergerakan organisasi kemasyarakatan tersebut terdapat hal-hal yang bertentangan dengan prinsip-prinsip kehidupan yang diamanatkan oleh Pancasila dan peraturan perundang-undangan yang berlaku, bukan berarti proses pembubaran yang dilakukan oleh pemerintah dapat diamini begitu saja. Sebab kewenangan yang dimiliki oleh pemerintah Indonesia berpotensi menimbulkan keputusan yang parsial tanpa mempertimbangkan aspek keadilan dan kemanfaatannya.

Wajar untuk dipahami apabila pembubaran tersebut didasarkan pada fakta bahwa organisasi kemasyarakatan tersebut tidak menjunjung tinggi prinsip saling menghargai dan menghormati sehingga Kementerian Hukum dan HAM bertindak atas nama pemerintah mencabut legalisasi organisasi kemasyarakatan yang dianggap telah melanggar ketentuan yang berlaku. Namun, harus disadari bahwa indonesia adalah negara hukum didasarkan pada Pasal 1 ayat (3) UUD NRI Tahun 1945 yang telah menegaskan bahwa, "Negara Indonesia adalah negara hukum".

Olehnya itu, Negara hukum sebagaimana disebut A.V. Dicey sebagai “The Rule of Law" memiliki karakteristik, yaitu: supremacy of law, equality before the law dan 
due process of law..$^{6}$ Menurut Atif Latipulhayat bahwa pembatasan kebebasan berserikat dan berkumpul dan juga pembubaran organisasinya mensyaratkan adanya pengadilan yang mandiri dan imparsial. Dengan perkataan lain harus dilakukan dengan proses yang adil atau due process of law. Due process of law bukan konsepsi teknis yang hanya menyangkut teknis dan mekanisme peradilan semata, akan tetapi ia adalah suatu proses dan perlakuan yang adil (just and fair treatment) yang memberikan tempat dan kesempatan kepada mereka yang hak dan kebebasannya terancam untuk membela hakhaknya. $^{7}$

Peran pengadilan menjadi sangat penting dalam rangka meneguhkan negara hukum yang dianut oleh Indonesia. Keterlibatan pengadilan dalam memutus sengketa pembubaran organisasi kemasyarakatan akan lebih mencerminkan objektifitas dalam penegakan hukum sebagai tujuan untuk memberikan keadilan. Dengan kata lain perlu didesain sebuah proses peradilan yang cepat, sederhana dan biaya ringan dalam rangka mendukung proses hukum yang akan diputus oleh pengadilan. Dengan adanya penerapan asas peradilan yang cepat, sederhana dan biaya ringan yang telah diamanatkan Undang-Undang Nomor 48 Tahun 2009 tentang Kekuasaan Kehakiman pada Pasal 2 ayat (4) dapat mempercepat proses penegakan hukum terhadap suatu organisasi kemasyarakatan yang diduga menyalahi peraturan perundang-undangan di I.

\section{B. Pengaturan Pembubaran Organisasi Kemasyarakatan di Indonesia}

Asas organisasi kemasyarakatan yaitu tidak bertentangan dengan Pancasila dan Undang-Undang Dasar Negara Republik Indonesia Tahun 1945. Kemudian organisasi kemasyarakatan dapat mencantumkan ciri tertentu yang mencerminkan kehendak dan cita-cita organisasi kemasyarakatan yang tidak bertentangan dengan Pancasila dan UUD NRI Tahun 1945. Sedangkan dilihat dari sifatnya bahwa organisasi kemasyarakatan bersifat sukarela, sosial, mandiri, nirlaba, dan demokratis. ${ }^{8}$

\footnotetext{
${ }^{6}$ Jimly Asshiddiqie, Konstitusi dan Konstitusionalisme Indonesia (Jakarta: Setjen Kepaniteraan Mahkamah Konstitusi, 2010), 122.

${ }^{7}$ Latipulhayat, "Due Process of Law," 2.

${ }^{8}$ Republik Indonesia, Undang Undang Nomor 17 Tahun 2013 tentang Organisasi Kemasyarakatan, Pasal 2, Pasal 3, dan Pasal 4
} 
Pasal tersebut bermakna bahwa dalam menjalankan ekspresi dan kebebasan sebuah organisasi kemasyarakatan harus berada pada jalur yang konstitusional berdasarkan cita-cita dan kehendak Pancasila dan UUD NRI Tahun 1945. Memang harus disadari bahwa organisasi kemasyarakatan memiliki tujuan dan fungsi yang variatif, tetapi undang-undang memberikan batasan kepada organisasi kemasyarakatan untuk bisa menjalankan tugasnya sebagai wadah perhimpunan yang memiliki nilai dan manfaat kepada masyarakat. begitupun dengan larangan-larangan yang diatur oleh undang-undang sudah sangat jelas sebagai peringatan kepada organisasi kemasyarakatan agar tidak membuat pelanggaran yang berakibat pada pemberian sanksi kepada organisasi kemasyarakatan tersebut. Dengan demikian organisasi kemasyarakatan tidak dapat bertindak sewenang-wenang maupun melakukan kekerasan/perbuatan anarkis dengan mengatasnamakan kebenaran parsial yang dapat merugikan organisasi kemasyarakatan yang bersangkutan guna menjaga ketertiban serta ketentraman kehidupan berbangsa dan bernegara.

Sanksi yang paling berat diberikan kepada organisasi kemasyarakatan yaitu pencabutan status hukum atau izin aktivitasnya sehingga dengan demikian organisasi kemasyarakatan dinyatakan bubar secara sendirinya. Tata cara pembubaran Organisasi Kemasyarakatan berdasarkan ketentuan sebelumnya dalam Undang-Undang Nomor 17 Tahun 2013 tentang Organisasi Kemasyarakatan:

1) Permohonan pembubaran Organisasi Kemasyarakatan berbadan hukum, diajukan ke pengadilan negeri oleh kejaksaan hanya atas permintaan tertulis dari Menteri Hukum dan HAM;

2) Permohonan tersebut diajukan kepada ketua pengadilan negeri sesuai tempat domisili hukum Organisasi Kemasyarakatan dengan disertai bukti penjatuhan sanksi administratif oleh Pemerintah atau Pemerintah Daerah;

3) Dalam hal permohonan tidak disertai bukti penjatuhan sanksi administratif oleh Pemerintah atau Pemerintah Daerah, permohonan pembubaran Organisasi Kemasyarakatan berbadan hukum tidak dapat diterima;

4) Setelahnya di ajukan permohonan, pengadilan negeri menetapkan hari sidang dalam jangka waktu paling lama 5 (lima) hari kerja terhitung sejak tanggal pendaftaran permohonan;

5) Surat pemanggilan sidang pemeriksaan pertama harus sudah diterima secara patut oleh para pihak paling lambat 3 (tiga) hari sebelum pelaksanaan sidang; 
6) Dalam sidang pemeriksaan Organisasi Kemasyarakatan sebagai pihak termohon diberi hak untuk membela diri dengan memberikan keterangan dan bukti di persidangan;

7) Permohonan pembubaran Organisasi Kemasyarakatan harus diputus oleh pengadilan negeri dalam jangka waktu paling lama 60 hari terhitung sejak tanggal permohonan dicatat dan harus diucapkan dalam sidang terbuka untuk umum. Jangka waktu ini dapat diperpanjang paling lama 20 hari atas persetujuan Ketua Mahkamah Agung;

8) Pengadilan Negeri menyampaikan salinan putusan pembubaran Organisasi Kemasyarakatan kepada pemohon, termohon, dan Menteri Hukum dan HAM dalam jangka waktu paling lama 7 (tujuh) hari terhitung sejak tanggal putusan diucapkan dalam sidang terbuka untuk umum. ${ }^{9}$

Penjatuhan sanksi administrasi pembubaran Organisasi Kemasyaraktan berdasarkan Undang-Undang Nomor 17 Tahun 2013 tentang Organisasi Kemasyarakatan dapat dilihat bahwa penjatuhan sanksi administrasi dilakukan melalui putusan pengadilan yang telah memperoleh kekuatan hukum tetap, setelah itu baru pemerintah dapat menjatuhkan sanksi pencabutan status badan hukum organisasi kemasyarakatan.

Pembubaran organisasi kemasyarakatan berdasarkan Undang-Undang Nomor 16 Tahun 2017 tentang Penetapan Peraturan Pemerintah Pengganti Undang-Undang Nomor 2 Tahun 2017 tentang Perubahan atas Undang-Undang Nomor 17 Tahun 2013 tentang Organisasi Kemasyarakatan. Organisasi Kemasyarakatan adalah organisasi yang didirikan dan dibentuk oleh masyarakat secara sukarela berdasarkan kesamaan aspirasi, kehendak, kebutuhan, kepentingan, kegiatan, dan tujuan untuk berpartisipasi dalam pembangunan demi tercapainya tujuan Negara Kesatuan Republik Indonesia yang berdasarkan Pancasila dan UUD NRI Tahun $1945 .{ }^{10}$

Ketentuan dalam undang-undang a quo, dijelaskan juga berkaitan dengan ajaran atau paham yang bertentangan dengan Pancasila antara lain ajaran ateisme, komunisme/marxisme-leninisme, atau paham lain yang bertujuan untuk

\footnotetext{
${ }^{9}$ Republik Indonesia, Undang Undang Nomor 17 Tahun 2013 tentang Organisasi Kemasyarakatan, Pasal 70-Pasal 72.

${ }^{10}$ Republik Indonesia, Undang-Undang Nomor 16 Tahun 2017 tentang tentang Penetapan Peraturan Pemerintah Pengganti Undang-Undang Nomor 2 Tahun 2017 tentang Perubahan atas UndangUndang Nomor 17 Tahun 2013 tentang Organisasi Kemasyarakatan, Pasal 1 angka (1)
} 
Pembubaran Organisasi Kemasyarakatan dalam Perspektif Siyasah Syar'iyyah dan Negara Hukum

mengganti/mengubah Pancasila dan UUD NRI Tahun $1945 .{ }^{11}$ Undang-undang a quo, larangan-larangan organisasi kemasyarakatan sebagaimana diatur pada Pasal 59 menjelaskan sebagai berikut:

1) Menggunakan nama, lambang, bendera, atau atribut yang sama dengan nama, lambang, bendera, atau atribut lembaga pernerintahan;

2) Menggunakan dengan tanpa izin nama, lambang, bendera negara lain atau lembaga/badan internasional menjadi nama, lambang, atau bendera Organisasi Kemasyarakatan; dan/atau

3) Menggunakan nama, lambang, bendera, atau tanda gambar yang mempunyai persamaan pada pokoknya atau keseluruhannya dengan nama, lambang, bendera, atau tanda gambar Organisasi Kemasyarakatan lain atau partai politik.

4) Menerima dari atau memberikan kepada pihak manapun sumbangan dalam bentuk apapun yang bertentangan dengan ketentuan peraturan perundangundangan; dan/ atau

5) Mengumpulkan dana untuk partai politik.

6) Melakukan tindakan permusuhan terhadap suku, agama, ras, atau golongan;

7) Melakukan penyalahgunaan, penistaan, atau penodaan terhadap agama yang dianut di Indonesia;

8) Melakukan tindakan kekerasan, mengganggu ketenteraman dan ketertiban umum, atau merusak fasilitas umum dan fasilitas sosial; dan/atau

9) Melakukan kegiatan yang menjadi tugas dan wewenang penegak hukum sesuai dengan ketentuan peraturan perundang-undangan.

10) Menggunakan nama, lambang, bendera, atau simbol organisasi yang mempunyai persamarn pada pokoknya atau keseluruhannya dengan nama, lambang, bendera, atau simbol organisasi gerakan separatis atau organisasi terlarang;

11) Melakukan kegiatan separatis yang mengancam kedaulatan Negara Kesatuan Republik Indonesia; dan/atau

12) Menganut, mengembangkan, serta menyebarkan ajaran atau paham yang bertentangan dengan Pancasila. ${ }^{12}$

Mekanisme pembubaran Organisasi Kemasyarakatan berdasarkan UndangUndang Nomor 16 Tahun 2017 tentang Penetapan Peraturan Pemerintah Pengganti Undang-Undang Nomor 2 Tahun 2017 tentang Perubahan Atas Undang-Undang Nomor 17 Tahun 2013 tentang Organisasi Kemasyarakatan menjadi Undang-Undang diatur pada Pasal 62 yang menjelaskan bahwa:

\footnotetext{
${ }^{11}$ Republik Indonesia, Undang-Undang Nomor 17 Tahun 2013 tentang Organisasi Kemasyarakatan, Pasal 59 ayat 4 dan Pasal 59 ayat 4 huruf c (penjelasannya).

${ }^{12}$ Republik Indonesia, Undang-Undang Nomor 17 Tahun 2013 tentang Organisasi Kemasyarakatan, Pasal 59.
} 
1) Terhadap Organisasi Kemasyarakatan yang melakukan pelanggaran diberikan peringatan tertulis 1 kali dalam waktu 7 hari kerja sejak tanggal yang diterbitkan peringatan.

2) Dalam hal Organisasi Kemasyarakatan tidak mematuhi peringatan tertulis dengan jangka waktu yang telah di tentukan makan Menteri dan Menteri yang menyelenggarakan urusan pemerintahan dibidang hukum dan HAM sesuai dengan kewenangannya menjatuhkan sanksi penghentian kegiatan.

3) Dalam hal Organisasi Kemasyarakatan tidak mengindahkan sanksi penghentian kegiatan, Menteri dan Menteri yang menyelenggarakan urusan pemerintahan dibidang hukum dan HAM sesuai kewenangannya melakukan pencabutan surat keterangan terdaftar atau pencabutan status badan hukum. ${ }^{13}$

Selanjutnya pada Pasal 80A menegaskan bahwa pencabutan status badan hukum organisasi kemasyarakatan dinyatakan bubar berdasarkan undang-undang ini. Berdasarkan Pasal 62 dan Pasal 80A tersebut, Pemerintah atau Pemerintah Daerah sesuai dengan lingkup tugas dan kewenangannya masih tetap menjatuhkan sanksi administratif, namun dalam hal ini tidak terdapat putusan pengadilan yang memiliki kekuatan hukum tetap guna memberikan legalitas dalam hal pembubaran organisasi kemasyarakatan. Dengan demikian, aturan diatas menegasikan kewenangan pengadilan untuk memutus sengketa pembubaran organisasi kemasyarakatan sehingga berkaitan dengan segala bentuk pemberian sanksi sampai pada pembubaran organisasi kemasyarakatan menjadi kewenangan penuh pemerintah.

Substansi materi yang mengatur tentang pembubaran organisasi kemasyarakatan sebagaimana dijelaskan dalam Undang-Undang Nomor 17 Tahun 2013 maupun Undang-Undang Nomor 16 Tahun 2017 perlu dielaborasi dengan prinsipprinsip dasar di dalam konstitusi Republik Indonesia, yaitu Pasal 1 ayat (3) UUD NRI Tahun 1945 yang merupakan pengukuhan dari prinsip yang dituangkan dalam Penjelasan Umum UUD NRI Tahun 1945 yaitu Negara Indonesia berdasar atas hukum tidak berdasar atas kekuasaan belaka.

Penjelasan UUD NRI Tahun 1945 pada masa lalu, sebenarnya indonesia disebut secara jelas menganut rectsstaat, namun pada saat amandemen UUD istilah rechtsstaat ditiadakan karena pasal 1 ayat (3) menjadi indonesia adalah negara hukum sudah

\footnotetext{
${ }^{13}$ Republik Indonesa, Undang Undang No 16 Tahun 2017 tentang Organisasi Kemasyarakatan, Pasal 62 dan Pasal 80A.
} 
Pembubaran Organisasi Kemasyarakatan dalam Perspektif Siyasah Syar'iyyah dan Negara Hukum

mengakomodir secara subtansial. Istilah rechtsstaat tidak dicantumkan supaya rechtsstaat dan the rule of law dalam sistem hukum indonesia keduanya bisa digunakan. Dengan demikian indonesia bisa menganut kebenaran itu ada di undangundang yang merupakan ajaran paham legisme, tapi juga menganut bahwa hakim bisa mencari keadilan sendiri tanpa tersandera undang-undang yang merupakan ciri khas dari paham the rule of law. Dengan demikian hakim lebih fleksibel dalam membuat putusan-putusannya. ${ }^{14}$

Selain itu, pentingnya sistem 'check and balances' (pengawasan dan keseimbangan) dalam prinsip konstitusi indonesia perlu diperhatikan secara seksama. Hal ini diwujudkan dari adanya jaminan kekuasaan kehakiman yang merdeka sebagaimana dijelaskan pada Pasal 24 UUD NRI Tahun 1945. Terpenuhinya jaminan akses warga negara dalam rangka mempertahankan haknya pada peradilan yang merdeka adalah bagian yang tidak terpisahkan dari terwujudnya jaminan kekuasaan kehakiman yang merdeka. Bagaimanapun juga, konstitusi telah mengatur hak untuk mendapatkan pengakuan, jaminan, perlindungan, dan kepastian hukum Pasal 28D ayat (1) UUD NRI Tahun 1945 yang di dalam sebuah negara hukum terwujud dengan adanya mekanisme kontrol atas penggunaan kewenangan yang dijalankan oleh suatu kekuasaan kehakiman yang merdeka Pasal 1 ayat (3) juncto Pasal 24 UUD NRI Tahun 1945.

\section{Telaah Siyasah Syari'iyah terhadap Pembubaran Organisasi Kemasyarakatan}

Secara etimologi siyasah syar'iyyah berasal dari kata syara'a yang artinya sesuatu sesuatu yang berusuan dengan politik atau peraturan yang bersifat syar'i. Lebih lanjut Ibnu Akil berpendapat secara terminologis dapat digambarkan bahwa sesuatu perbuatan yang menggiring manusia dekat dengan kemaslahatan dan terhindar dari

\footnotetext{
${ }^{14}$ Adhelano Tuakia, Indonesia di Persimpangan Rechtsstaat dan The Rule of Law, dalam https://www.kompasiana.com/adhelanot uakia/54f961e1a3331178178b4c1b/indonesia-dipersimpanganrechtsstaat-the-rule-of-law, diakses pada tanggal 10 Agustus 2019.
} 
kerusakan. ${ }^{15}$ Siyasah syar'iyyah dapat diartikan pengurusan masalah kenegaraan dengan ketentuan kebijaksanaan yang berdasarkan syariat. ${ }^{16}$

Berbicara siyāsah syar'iyyah, tidak lepas dari hubungan pemerintah dan masyarakat. Relasi manusia dan Negara bertumpu pada pertimbangan pemikiran dan hadist. Rasionalisasinya berada pada kebutuhan universal semua manusia tanpa peduli apakah mereka menganut suatu agama atau tidak agar selalu bekerjasama, bergabung dan menikmati segala sesuatu dari sebuah kepemimpinan yang bisa memberikan manfaat untuk mereka. Hal tersebut juga diperkuat dengan landasan dari sunnah nabi Muhammad saw. Beliau menganjurkan dalam beberapa sunnah atau hadis Nabi saw. yang menekankan perlunya kepemimpinan dan pemerintahan. ${ }^{17}$

Pada masa Rasulullah saw. sudah berada di Madinah, Allah swt. memberi isyarat tentang adanya fungsi-fungsi legislatif, eksekutif dan yudikatif di dalam suatu negara. Hal itu diisyaratkan oleh Allah swt. di dalam firman-Nya:

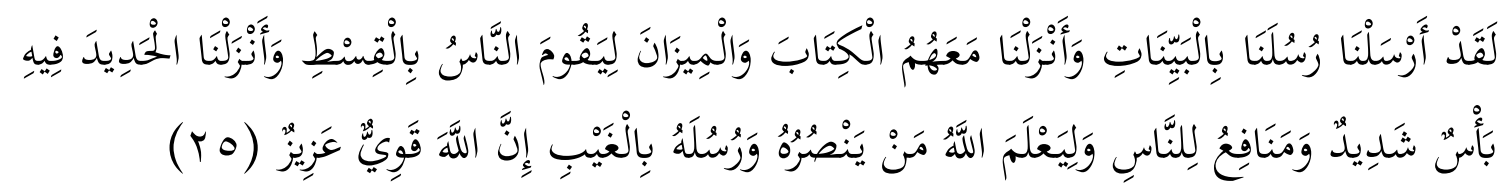

Terjemahnya:

Sungguh, Kami telah mengutus rasul-rasul Kami dengan bukti-bukti yang nyata dan Kami turunkan bersama mereka kitab dan neraca (keadilan) agar manusia dapat berlaku adil. Dan Kami menciptakan besi yang mempunyai kekuatan hebat dan banyak manfaat bagi manusia, dan agar Allah mengetahui siapa yang menolong (agama)-Nya dan rasul-rasul-Nya walaupun (Allah) tidak dilihatnya. Sesungguhnya Allah Mahakuat, Mahaperkasa (QS. al-Ḥadid/57: 25). ${ }^{18}$

Kepemimpinan Nabi Muhammad saw. sebagai Kepala Negara pada praktek pemerintahan yang dilakukan sangat nampak pelaksanaan tugas-tugas pemerintahan yang tidak terjadi pemusatan kekuasaan pada diri beliau. Beliau diakui sebagai pemimpin tertinggi dalam Piagam Madinah, yang berarti pemegang kekuasaan

\footnotetext{
${ }^{15}$ Wahbah Zuhaily, Ushul Fiqh: Kuliyat Da’wah Al Islami (Jakarta :Radar Jaya Pratama,1997), 89.

${ }^{16}$ Muhammad Iqbal, Fiqih Siyasah (Jakarta: Kencana, 2014), 5.

${ }^{17}$ Usman Jafar, Hukum Tata Negara Islam 2 Telaah Atas Pengolaan Pemerintah dan Diplomasi dalam Bingkai Syari'ah (Watampone: Penerbit Syahadah, 2016), 184.

${ }^{18}$ Kementerian Agama RI., Ummul Mukminin: Al-Qur'an dan Terjemahan untuk Wanita (Jakarta: Wali, 2010), 541.
} 
Pembubaran Organisasi Kemasyarakatan dalam Perspektif Siyasah Syar'iyyah dan Negara Hukum

legislatif (al-sulthah al-tasyri'iyah), eksekutif (al-sulthah al-tanfidziyah) dan yudikatif (al-sulthah al-qadha'iyah). Meskipun teori pemisahan atau pembagian kekuasaan belum ada pada saat itu, namun beliau telah mempraktekannya dengan cara mendelegasikan sebagaian kewenangan kepada para sahabat yang dianggap cakap dan mampu untuk menjalankan tugas-tugas eksekutif dan yudikatif. ${ }^{19}$

Tugas lembaga yudikatif (al-sulthah al-qadha'iyah) adalah mempertahankan hukum dan perundang-undangan yang telah diciptakan oleh lembaga legislatif. Sejarah Islam telah mencatat bahwa kekuasaan lembaga ini biasanya meliputi wilayah alhisbah (lembaga peradilan untuk menyelesaikan perkara-perkara pelanggaran ringan seperti kecurangan dan penipuan dalam bisnis)/ wilayah al-qadha' (lembaga peradilan yang memutuskan perkara-perkara antara sesama warganya, baik perdata maupun pidana) dan wilayah al-mazhalim (lembaga peradilan yang menyelesaikan perkara penyelewengan pejabat negara dalam melaksanakan tugasnya, seperti pembuatan keputusan politik yang merugikan dan melanggar kepentingan atau hak-hak rakyat serta perbuatan pejabat negara yang melanggar HAM rakyat). ${ }^{20}$

Peran lembaga yudikatif (al-sulthah al-qadha'iyah) pada zaman itu, membuat rakyat tunduk terhadap perintah pengadilan yang objektif dalam membuat keputusankeputusan hukum. Kondisi tersebut merupakan sebuah legacy yang diberikan oleh Nabi Muhammad saw. untuk bagaimana tetap mempertahankan hukum Tuhan sebagai norma tertinggi. Bahkan dalam rangka menjaga prinsip-prinsip abadinya, pada saat Islam menegakkan negaranya yang menjadi hakim pertama adalah Rasulullah saw. dan fungsi kekuasaan tersebut dilaksanakan telah sesuai dengan hukum Tuhan. Kemudian Rasulullah saw. menyampaikan kepada para orang-orangnya pada saat itu sehingga mereka telah memutuskan untuk melanjutkannya dan tidak ada suatu pilihan yang lain melainkan melanjutkan apa yang telah diwarisi oleh Rasulullah saw. yang mana segala keputusan harus didasarkan pada hukum Tuhan. ${ }^{21}$

\footnotetext{
${ }^{19}$ J. Suyuthi Pulungan, Fiqh Siyasah, Ajaran Sejarah dan Pemikiran (Jakarta: PT Raja Grafindo Persada, 2002), 97.

${ }^{20}$ Muhammad Iqbal, Fiqh Siyasah, 137.

${ }^{21}$ Abu A'la Maududi, The Islamic Law And Constitution, terj. Asep Hikmat, Sistem Politik Islam (Bandung: Mizan, 1990), 249.
} 
Pelibatan lembaga yudikatif dalam menilai pelanggaran yang dilakukan oleh organisasi kemasyarakatan menjadi sangat penting. Sebab pada ranah pengadilan segala bentuk pertimbangan hukum dan objektifitas dalam mengadili organisasi kemasyarakatan dapat diterima oleh para pihak. Pada titik ini, pengadilan adalah instrumen yang paling tepat untuk menilai sebuah kebenaran materil terhadap pelanggaran yang dilakukan oleh organisasi kemasyarakatan.

Pasca Reformasi, posisi dan peran organisasi kemasyarakatan tampak bergeser. Euforia Reformasi dan demokratisasi Pasca Reformasi membuat organisasi kemasyarakatan kembali terpolarisasi dalam arus ideologi dan politik. Pasca Reformasi juga ditandai dengan menjamurnya ribuan organisasi kemasyarakatan baru. Kategori dan definisi organisasi kemasyarakatan pada era ini juga semakin berkembang luas dengan beragam persilangan arus kepentingan politik dan ideologi baik dalam skala nasional dan internasional. Keberadaan Negara/Pemerintah Pasca Reformasi seringkali terjebak dalam posisi yang saling behadap-hadapan karena dua faktor utama. Pertama, rendahnya kepercayaan sebagian pemimpin Ormas tertentu pada Negara/Pemerintah. Kedua, masih dijumpai adanya kesalahpahaman atas peran Negara/Pemerintah dihadapan para pendukung Ormas. ${ }^{22}$

Selain fenomena tersebut, pasca reformasi juga ditandai adanya tindakan kekerasan dan anarkisme yang dilakukan Ormas tertentu. Obyek anarkisme ini tidak lagi semata-mata pada sejumlah kantor Pemerintahan. Aksi anarkisme Ormas juga ditujukan pada institusi media massa. Tidak hanya itu aksi anarkisme dan kekerasan juga terjadi antar para pendukung Ormas. Akar penyebab adanya tindakan anarkisme dan kekerasan ini adakalanya tidak hanya sebatas pada kepentingan politik yang bersifat jangka pendek. Lebih dari itu, konflik antar Ormas seringkali bersumber dari akar konflik yang bersifat laten, yaitu adanya pertentangan landasan ideologi yang mereka yakini. Pasca Reformasi, tampak masih terbuka potensi besar dimana perbedaan landasan ideologi yang dianut oleh masing-masing Ormas justru kian mendegradasi imaji ke-Indonesia-an. Anarkisme yang dilakukan oleh Ormas tertentu ini tentu sangat kontras dengan keberadaan Ormas masa Pra Kemerdekaan dimana

\footnotetext{
${ }^{22}$ Gamawan Fauzi, "Urgensi UU Ormas dalam Memperkokoh NKRI," Jurnal Kementerian Sekretariat Negara RI No. 29, Maret 2015; 60.
} 
Pembubaran Organisasi Kemasyarakatan dalam Perspektif Siyasah Syar'iyyah dan Negara Hukum

mereka secara kolektif menyemaikan benih Nasionalisme dan ke-Indonesia-an. Dinamika Ormas yang demikian tentu jauh dari yang diharapkan. ${ }^{23}$

Permasalahan tersebut menunjukan bahwa semakin besar ruang kebebasan yang diberikan oleh negara justru membahayakan terhadap keamanan negara. Hal ini yang harus dihindari karena tindakan anarkisme dan radikalisme oleh oknum organisasi kemasyarakatan sangat jauh dari nilai-nilai amar ma'ruf nahi munkar sehingga pengadilan harus mampu membuat keputusan hukum yang objektif dan adil terhadap pembubaran organisasi kemasyarakatan.

\section{Mekanisme Pembubaran Organisasi Kemasyarakatan Yang Ideal Dalam Perspektif Negara Hukum}

Suatu negara dapat dikatakan sebagai negara hukum apabila memenuhi unsurunsur negara hukum. Friedrich Julius Stahl sebagaimana dikutip oleh Achmad Irwan Hamzani mengemukakan ciri-ciri suatu negara hukum, yaitu adanya pengakuan atas hakhak dasar manusia, adanya pembagian kekuasaan, pemerintahan berdasarkan peraturan, dan adanya Peradilan Tata Usaha Negara. ${ }^{24}$

Sementara dalam sistem Anglo Saxon sebagaimana dikemukakan oleh A.V. Dicey yang dikutip oleh Wahyudi Djafar menjelaskan bahwa negara hukum dalam perspektif the rule of law memiliki tiga karakteristik, yaitu: tegaknya supremasi hukum (supremacy of law), persamaan di depan hukum (equality before the law), dan adanya jaminan serta mekanisme perlindungan diri atas hak (due process of law). Supremasi hukum berarti hukum mengatur semua perilaku/perbuatan warga negara, sehingga seseorang dapat dihukum dengan hukum itu sendiri karena telah melanggar hukum. Lebih lanjut Dicey menerangkan bahwa tentang persamaan di depan hukum, semua warganegara memiliki derajat yang sama dihadapan hukum negara, yang dijalankan oleh peradilan umum. The Rule of law tidak mengenal adanya pengecualian bagi pejabat pemerintah atau orang-orang tertentu terhadap hukum yang mengatur warganegara secara keseluruhan, seperti halnya pada pengadilan administratif (droit

\footnotetext{
${ }^{23}$ Ibid., 61 .

${ }^{24}$ Achmad Irwan Hamzani, "Menggagas Indonesia Sebagai Negara Hukum yang Membahagiakan Rakyatnya,” Jurnal Yustisia, Edisi 90 September - Desember 2014; 137.
} 
administratif). Kemudian Dicey menjelaskan kaitannya dengan due process of law bahwa segala hasil dari keputusan parlemen sebagai simbolisasi raja dan demos (warga) serta putusan pengadilan harus memberikan jaminan atas hak-hak pribadi. Dengan demikian, apa yang menjadi hasil dari hukum negara menjadi konstitusi yang didalamnya terdapat substansi jaminan hak-hak pribadi warganegara. ${ }^{25}$

Secara nasional perlindungan terhadap hak-hak terkait dengan kebebasan berserikat, berkumpul, dan mengeluarkan pendapat diatur dalam UUD NRI Tahun 1945 dan Undang-Undang Nomor 39 Tahun 1999 tentang Hak Asasi Manusia. UUD NRI Tahun 1945 telah menjamin tiap orang berhak atas kebebasan berserikat, berkumpul dan berpendapat sebagaimana diatur dalam pasal 28E ayat (3) yang menyatakan bahwa setiap orang berhak atas kebebasan berserikat, berkumpul, dan mengeluarkan pendapat. Ketentuan UUD 1945 tersebut kemudian ditegaskan kembali di dalam Pasal 24 Undang-Undang Nomor 39 Tahun 1999 tentang Hak Asasi Manusia, yang menyatakan bahwa setiap orang berhak untuk berkumpul, berapat, dan berserikat untuk maksud-maksud damai.

Penegasan Indonesia sebagai negara hukum telah di atur dalam UUD NRI Tahun 1945 pada Pasal 1 ayat 3 yang menjelaskan bahwa Negara Indonesia adalah Negara Hukum. Menurut Tahir Azhary bahwa negara hukum merupakan suatu genus begrip yang memiliki lima konsep, yaitu nomokrasi Islam yang merupakan konsep negara hukum berdasarkan Alquran dan Sunnah, negara hukum dalam konsep Eropa Kontinental yang disebut rechsstaats, konsep rule of law di negara-negara yang common law, konsep socialist leglity di negara ekskomunis serta konsep negara hukum Pancasila. $^{26}$

Indonesia sebagai negara hukum memang mengatur pembatasan mengenai hak setiap warga negara, hal ini sebagaimana dalam UUD NRI Tahun 1945 Pasal 28 J Ayat 2 dimana dijelaksan bahwa dalam menjalankan hak dan kebebasannya, setiap orang wajib tunduk kepada pembatasan yang telah ditetapkan dengan undang-undang dengan

\footnotetext{
${ }^{25}$ Wahyudi Djafar, "Menegaskan Kembali Komitmen Negara Hukum: Sebuah Catatan Atas Kecenderungan Defisit Negara Hukum di Indonesia," Jurnal Konstitusi, Volume 7, Nomor 5, Oktober $2010 ; 153$.

${ }^{26}$ Azhary Muhammad Tahir, Beberapa Aspek Hukum Tata Negara, Hukum Pidana, dan Hukum Islam (Jakarta: Pernada Media Group, 2012), 48.
} 
maksud semata-mata untuk menjamin pengakuan serta penghormatan atas hak dan kebebasan orang lain dan untuk memenuhi tuntutan yang adil sesuai dengan pertimbangan moral, nilai-nilai agama, keamanan, dan ketertiban umum dalam suatu masyarakat demokratis. $^{27}$

Berdasarkan unsur-unsur yang berlaku umum bagi setiap negara hukum sebagai berikut:

1) Sistem pemerintahan didasarkan pada kehendak dan kedaulatan rakyat.

2) Hukum atau peraturan perundang-undangan harus menjadi landasan pemerintah dalam melaksanakan tugas dan kewajibannya.

3) Terdapat perlindungan hak asasi manusia (warga negara).

4) Memiliki pembagian kekuasaan yang jelas dalam negara.

5) Terdapat peradilan yang independen bebas dan mandiri serta tidak dibawah pengaruh/tekanan pemeritah.

6) Terdapat partisipasi warganegara untuk terlibat mengawasi kinerja pemerintah.

7) Sistem perekonomian yang berkeadilan terhadap warganegara.

8) Sumber daya yang diperlukan bagi kemakmuran warga negara. ${ }^{28}$

Zippelius memandang sebagaimana dikemukakan oleh Hamid S. Attamimi, menyebutkan bahwa prinsip negara hukum adalah untuk membatasi perluasan dan penggunaan kekuasaan secara totaliter dan sewenang-wenang. Prinsip-prinsip yang harus ditegakkan meliputi jaminan terhadap perlindungan hak asasi manusia, adanya pembagian kekuasaan secara pasti dan jelas, penyelenggaraan pemerintahan yang berdasar pada undang-undang, dan adanya pengawasan judicial terhadap penyelenggaraan pemerintahan. ${ }^{29}$

Konsekuensi Indonesia sebagai negara hukum, yaitu penegakan hukum dan keadilan dalam rangka menjamin pelaksanaan hak-hak asasi manusia merupakan

\footnotetext{
${ }^{27}$ Republik Indonesia, Undang Undang Dasar Negara Republik Indonesia Tahun 1945, Pasal 28 $\mathrm{J}$ ayat 2.

${ }^{28}$ Titik Triwulan dan Ismu Gunadi Widodo, Hukum Tata Usaha Negara dan Hukum Acara Peradilan Tata Usaha Negara Indonesia (Jakarta: Prenadamedia Group, 2011), 270.

${ }^{29}$ A. Hamid S. Attamimi, "Peranan Keputusan Presiden Republik Indonesia dalam Penyelenggaraan Pemerintahan Negara: Suatu Studi Analisis Mengenai Keputusan Presiden yang Berfungsi Pengaturan dalam Kurun Waktu Pelita I-Pelita IV," Disertasi (Jakarta: Universitas Indonesia. 1990), 213.
} 
bagian dari penyelenggaraan peradilan dalam bingkai kekuasaan kehakiman yang merdeka, diwujudkan dan dilakukan oleh sebuah Mahkamah Agung beserta badan peradilan yang berada di bawahnya, yaitu lingkungan peradilan umum, peradilan agama, peradilan militer, peradilan tata usaha negara, dan oleh sebuah Mahkamah Konstitusi, sebagaimana amanat ketentuan Pasal 1 ayat (3), Pasal 24 ayat (1) dan ayat (2), serta Pasal 28I ayat (5) UUD 1945. Dengan kata lain, fungsi kekuasaan kehakiman menjadi penting untuk menyeimbangi kekuatan dari pemerintah dalam menjalankan kewenangannya. Hal ini sangat krusial dalam bangunan negara hukum indonesia sebagai bentuk komitmen dan konsistensi penyelenggara negara agar tidak terjebak pada pemusatan kekuasaan yang mutlak.

Menurut Atip bahwa due process tidak bisa dilepaskan dan melepaskan diri dari HAM. Dengan perkataan lain dapat dikatakan bahwa due process of law adalah HAM itu sendiri. Dalam konteks ini, due process of law mensyaratkan bukan hanya adanya due process dalam pengertian terpenuhinya hak-hak prosedural dasar (basic procedural rights), tapi juga terlindunginya hak-hak substantif dasar (basic substantive rights). Hak substantif adalah hak-hak umum yang dimiliki oleh seseorang untuk melakukan sesuatu atau untuk memiliki sesuatu, meskipun pemerintah berkeinginan yang sebaliknya, misalnya, kebebasan untuk berbicara dan kebebasan untuk berserikat dan berkumpul. Hak prosedural adalah hak yang dimiliki seseorang untuk memperoleh layanan dari pemerintah secara adil. Meskipun pemerintah dengan alasan tertentu dapat mengurangi atau membatasi hak substantif yang dimiliki oleh seseorang, hal tersebut harus dilakukan dengan alasan yang dibenarkan dan dengan cara yang adil. Dengan demikian dapat dikatakan bahwa due process of law adalah bagian integral dalam perlindungan dan pemenuhan hak-hak subtantif seperti hak untuk berserikat dan berkumpul.

Lebih lanjut Atip menegaskan bahwa esensi dan substansi prinsip due process of law, sejatinya ia bukan formalitas terselenggaranya suatu proses peradilan, akan tetapi esensi dari peradilan tersebut yaitu harus dilakukan secara reasonable, just, dan proper. Dengan demikian, adanya pengadilan tidak dengan sendirinya merupakan due process of law, apabila tidak dilakukan dengan reasonable, just, dan proper. Misalnya, 
Pembubaran Organisasi Kemasyarakatan dalam Perspektif Siyasah Syar'iyyah dan Negara Hukum

pengadilan dilakukan setelah pemerintah mencabut hak-hak warga untuk berserikat dan berkumpul dalam hal pembubaran Ormas. Proses seperti ini jelas merupakan proses yang undue (tidak patut), karena kerugian sudah terjadi (the damage has been done) tanpa ada ruang dan kesempatan membela diri. Bukan suatu pembelaan apabila luka dan kerugian sudah diderita. ${ }^{30}$

Kondisi inilah yang menghendaki penerapan hukum sebaiknya diutamakan melalui pengadilan. Selain itu pula dapat menjaga konsistensi negara hukum yang salah satu indikatornya adalah pembagian kekuasaan yang jelas antara fungsi eksekutif dan yudikatif sehingga hukum yang abstrak dapat diterapkan kepada individu melalui putusan hakim sekaligus dapat mengontrol kekuasaan eksekutif untuk menjatuhi sanksi pembubaran kepada organisasi kemasyarakatan yang bermasalah. Mesti diakui bahwa peradilan memiliki fungsi yang kuat dalam menyeimbangkan dan mengawasi kinerja eksekutif dan legislatif khususnya berbicara mengenai penerapan hukum yang menyangkut orang banyak. Sebab permasalahan ini berbicara mengenai kebebasan berserikat dan berkumpul yang merupakan muatan dari Hak Asasi Manusia sebagai pilar dalam negara hukum. Olehnya, tidak bisa secara sepihak untuk mengeluarkan keputusan tanpa melalui uji kelayakan dari pengadilan berkaitan penerapan hukum yang dilakukan oleh eksekutif dan legislatif. Apapun kebijakan yang ditelurkan oleh pemerintah harus diuji di pengadilan yang independen dan imparsial dalam rangka memberikan kepastian hukum dan keadilan kepada organisasi kemasyarakatan yang bermasalah.

Penulis berpendapat bahwa peran pengadilan menjadi sangat penting digunakan sebagai alat negara dalam mengadili organisasi kemasyarakatan yang melanggar aturan-aturan negara berkaitan dengan kebebasan berserikat dan berkumpul. Hakim memiliki parameter yang jelas dalam mengukur telah terjadinya suatu pelanggaran hukum yang dilakukan oleh organisasi kemasyarakatan. Dengan kata lain, parameter yang dijadikan patokan oleh hakim mampu diterima oleh para pihak karena telah melalui proses penilaian terdahulu oleh pemerintah berupa pemberian sanksi administratif yang telah diberikan kepada organisasi kemasyarakatan yang melanggar

\footnotetext{
${ }^{30}$ Latipulhayat, "Due Process of Law," 3.
} 
aturan, sehingga hakim sebagai penilai akhir menguji secara formil maupun materil apakah sanksi yang sudah diberikan itu sudah sejalan dengan dengan peraturan perundang-undangan yang berlaku atau dengan penemuan hukum baru hakim dapat menganulir sanksi yang telah dijatuhkan oleh pemerintah kepada organisasi kemasyarakatan yang bermasalah. Hanya saja, berbicara mengenai proses penyelesaian di pengadilan memakan waktu yang cukup lama sehingga sulit untuk mengantisipasi aktivitas organisasi kemasyarakatan bermasalah yang bisa saja berpotensi akan melakukan hal yang sangat membahayakan untuk negara. Untuk mengatasi hal ini, perlu dilakukan penataan penyelesaian sengketa di pengadilan dengan menggunakan asas peradilan cepat, sederhana dan biaya ringan yang bisa menengahi proses penyelesaian sengketa yang ruwet.

Merujuk pada Pasal 2 ayat (4) Undang-Undang Nomor 48 Tahun 2009 tentang Kekuasaan Kehakiman berbunyi bahwa peradilan dilakukan dengan sederhana, cepat, dan biaya ringan, yang dapat dijadikan sebagai ius constituendum dan dijadikan model untuk penyelesaian sengketa pembubaran organisasi kemasyarakatan. Konsep ini sangat penting untuk menata kembali pembubaran ormas yang dilakukan saat ini sebagaimana diatur dalam Undang-Undang Nomor 16 Tahun 2017. Urgensi penerapan asas peradilan dilakukan dengan sederhana, cepat, dan biaya ringan untuk mempercepat proses penegakan hukum agar pemerintah dapat mengantisipasi segala bentuk ancaman yang muncul. Dengan demikian, keinginan pemerintah untuk menyederhanakan waktu alur pembubaran organisasi kemasyarakatan dapat ditengahi dengan menetapakan waktu selama 14 (empat belas) hari kepada pengadilan untuk memutus bersalah atau tidaknya organisasi kemasyarakatan yang diajukan pemerintah ke pengadilan. Olehnya, melibatkan pengadilan dalam penyelesaian sengketa ini, justru akan memperkuat pondasi bangunan negara hukum Indonesia yang berlandaskan pada Pancasila dan UUD NRI Tahun 1945.

\section{E. Kesimpulan}

Substansi materi yang mengatur tentang pembubaran organisasi kemasyarakatan sebagaimana dijelaskan dalam Undang-Undang Nomor 17 Tahun 2013 
Pembubaran Organisasi Kemasyarakatan dalam Perspektif Siyasah Syar'iyyah dan Negara Hukum

maupun Undang-Undang Nomor 16 Tahun 2017 perlu dielaborasi dengan prinsipprinsip dasar di dalam konstitusi Republik Indonesia, yaitu Pasal 1 ayat (3) UUD NRI Tahun 1945 yang merupakan pengukuhan dari prinsip yang dituangkan dalam Penjelasan Umum UUD NRI Tahun 1945 yaitu Negara Indonesia berdasar atas hukum, tidak berdasar atas kekuasaan belaka. UUD NRI Tahun 1945 menekankan pentingnya sistem 'check and balances' (pengawasan dan keseimbangan) yang mana perlu ada pembagian kekuasaan yang jelas antara fungsi eksekutif dan yudikatif. Artinya dalam permasalahan pembubaran organisasi kemasyarakatan sangat penting untuk melibatkan pengadilan untuk memutus pembubaran organisasi kemasyarakatan di Indonesia dengan cara melakukan penataan penyelesaian sengketa di pengadilan dengan menggunakan asas peradilan cepat, sederhana dan biaya ringan sehingga proses penyelesaian sengketa pembubaran organisasi kemasyarakatan bisa dilaksanakan secara efektif dan efisien. Pengadilan harus berperan dalam menilai sebuah pelanggaran yang dilakukan oleh organisasi kemasyarakatan yang tujuannya untuk menghindari keputusan parsial yang dilakukan oleh pemerintah yang justru menimbulkan persepsi buruk masyarakat terhadap kondisi penerapan negara hukum dan demokrasi di Indonesia.

\section{Daftar Pustaka}

Asshiddiqie, Jimly. Konstitusi dan Konstitusionalisme Indonesia. Jakarta: Setjen Kepaniteraan Mahkamah Konstitusi, 2010.

Attamimi, A. Hamid S. "Peranan Keputusan Presiden Republik Indonesia dalam Penyelenggaraan Pemerintahan Negara: Suatu Studi Analisis Mengenai Keputusan Presiden yang Berfungsi Pengaturan dalam Kurun Waktu Pelita IPelita IV.” Disertasi. Jakarta: Universitas Indonesia. 1990.

Djafar, Wahyudi. "Menegaskan Kembali Komitmen Negara Hukum: Sebuah Catatan Atas Kecenderungan Defisit Negara Hukum di Indonesia." Jurnal Konstitusi, Volume 7, Nomor 5, Oktober 2010.

Fauzi, Gamawan. "Urgensi UU Ormas dalam Memperkokoh NKRI," Jurnal Kementerian Sekretariat Negara RI No. 29, Maret 2015. 
Hamzani, Achmad Irwan. "Menggagas Indonesia Sebagai Negara Hukum yang Membahagiakan Rakyatnya." Jurnal Yustisia, Edisi 90 September - Desember 2014.

In'amuzzahidin, Muh. “Konsep Kebebasan Dalam Islam,” Jurnal at-Taqaddum, Vol. 7, No. 2, November 2015.

Iqbal, Muhammad. Fiqih Siyasah. Jakarta: Kencana, 2014.

Jafar, Usman. Hukum Tata Negara Islam 2 Telaah Atas Pengolaan Pemerintah dan Diplomasi dalam Bingkai Syari’ah. Watampone: Penerbit Syahadah, 2016.

Kementerian Agama RI. Ummul Mukminin: Al-Qur'an dan Terjemahan untuk Wanita. Jakarta: Wali, 2010.

Latipulhayat, Atip. "Due Process of Law," Jurnal Ilmu Hukum Padjajaran, Vol. 4 No. $2,2017$.

Maududi, Abu A'la. The Islamic Law And Constitution, terj. Asep Hikmat, Sistem Politik Islam. Bandung: Mizan, 1990.

Mursitama, Tirta Nugraha. Laporan Pengkajian Hukum Tentang Peran Dan Tanggungjawab Organisasi Kemasyarakatan Dalam Pemberdayaan Masyarakat. Jakarta: Pusat Penelitian Dan Pengembangan Sistem Hukum Nasional Badan Pembinaan Hukum Nasional Kementerian Hukum Dan Hak Asasi Manusia RI, 2011.

Pulungan, J. Suyuthi. Fiqh Siyasah, Ajaran Sejarah dan Pemikiran. Jakarta: PT Raja Grafindo Persada, 2002.

Republik Indonesa. Undang Undang No 16 Tahun 2017 tentang Organisasi Kemasyarakatan.

Republik Indonesia. Undang Undang Dasar Negara Republik Indonesia Tahun 1945.

Republik Indonesia. Undang Undang Nomor 17 Tahun 2013 tentang Organisasi Kemasyarakatan.

Republik Indonesia. Undang-Undang Nomor 16 Tahun 2017 tentang tentang Penetapan Peraturan Pemerintah Pengganti Undang-Undang Nomor 2 Tahun 2017 tentang Perubahan atas Undang-Undang Nomor 17 Tahun 2013 tentang Organisasi Kemasyarakatan.

Tahir, Azhary Muhammad. Beberapa Aspek Hukum Tata Negara, Hukum Pidana, dan Hukum Islam. Jakarta: Pernada Media Group, 2012.

Thalhah, HM. "Teori Demokrasi dalam Wacana Ketatanegaraan Perspektif Pemikiran Hans Kelse,” Jurnal Hukum Vol. 16 No. 3, Juli 2009. 
Pembubaran Organisasi Kemasyarakatan dalam Perspektif Siyasah Syar'iyyah dan Negara Hukum

Triwulan Titik, dan Ismu Gunadi Widodo. Hukum Tata Usaha Negara dan Hukum Acara Peradilan Tata Usaha Negara Indonesia. Jakarta: Prenadamedia Group, 2011.

Tuakiaa, Adhelano. Indonesia di Persimpangan Rechtsstaat dan The Rule of Law. https://www.kompasiana.com/adhelanotuakia/54f961e1a3331178178b4c1b/ind onesia-dipersimpangan-rechtsstaat-the-rule-of-law.

Wibowo, Catur, dan Herman Harefa, "Urgensi Pengawasan Organisasi Kemasyarakatan Oleh Pemerintah," Jurnal Bina Praja, Vol. 7, No. 1, Edisi Maret 2015.

Zuhaily, Wahbah. Ushul Fiqh: Kuliyat Da'wah al-Islami. Jakarta: Radar Jaya Pratama, 1997. 